\title{
Elizabeth's Epiphany in "Odour of Chrysanthemums"
}

\author{
Jing XIN \\ Department of Applied Foreign Languages, Wuhan Business University, Wuhan, \\ Hubei, China
}

Keywords: Epihany, Odour of chrysanthemums, D.H. Lawrence.

\begin{abstract}
This paper mainly focuses on the epiphany by Elizabeth of the story "Odour of Chrysanthemums", which is written by D. H. Lawrence. Through the analysis of the important instant of the story, we could learn a lot from the epiphany especially in the aspect of marriage and life and understand deeper of the story and the author, D. H. Lawrence.
\end{abstract}

"Odour of Chrysanthemums," regarded as one of D. H. Lawrence's most accomplished stories, was written in 1909 and evolved in three major versions. It first published in Ford Madox Hueffer's English Review in June 1911. And after several revisions between 1910 and 1914, it appeared in its final form in The Prussian Officer and Other Stories (1914). Most critical material on 'Odour of Chrysanthemums' concerns either its relationship to other writings by Lawrence, such as Sons and Lovers (1913), or the revisions of the story. However, my discussion focuses on the epiphany of the heroine, Elizabeth, at the end of the story in the final version, through which Lawrence gives a calmer and more judgmental condemnation of the failure of the marriage and reflects his more comprehensive understanding of husband and wife relations, and life and death because of his liberation from the influence of his beloved mother upon her death in 1910 and rebirth in his love, Frieda, since 1912.

In a language of "poetic realism" (Salgado, 2005: 127), Lawrence tells us a story, which is giving off a delicate sense, just like its title, "Odour of Chrysanthemums". The story stretches out in a mine community, on a dusk of dark winter days. And it is formally divided into two sections. In part one, Elizabeth Bates, a collier's wife, waits anxiously for her husband, Walter Bates, to return for dinner, concerns for his safety and at the same time angry at the trouble he has made for her by coming home late, and drunk, so often. She ponders their unsatisfactory relationship and tries to be calm before her two young children, Annie and John. In part two, after Elizabeth has sent the children to bed, she goes to the neighbors to ask about her husband. Meanwhile, her anger shifts to worry. At last, word comes that her husband has had an accident. No sooner, his body is brought into the house and laid out (undamaged because he died of suffocation). Washing the body with her mother-in-law, Elizabeth goes through a complex series of reactions, including curiosity, anger, sympathy, forgiveness, and cool appraisal. At last, watching the clear body, she sees the true self, her misunderstanding towards her husband and the utter isolation between them in spite of the role of their children. "She was grateful to death, which restored the truth" (Lawrence, 1998: 44). And she "knew she submitted to life" and "winced with fear and shame" from death (Lawrence, 1998: 45).

The moment of Elizabeth' revelation is an epiphany (a Greek word), which means "apparition" or "revelation" (Fargneli, 1995: 66). This word was first used by James Joyce to describe "the point of illumination" (Ibid.) of the main character in his early work, especially in the ending, and later became a term of such writing technique. Using epiphany in "Odour of Chrysanthemums", Lawrence sublimes the meaning of the short 
story, deepens the theme of isolation and sheds light on his understanding of man and woman relationship, and of life and death. It also reminds readers to do self-reflection. Without it, the story would have become a very ordinary one, just a narration of a piece of trivial family life. Although the death of the husband seems to be a surprise in the plot, we would have seen nothing more than the naked body and thought little after reading it.

The epiphany is "specifically the presence of the essence of something previously hidden" (Fargneli, 1995: 66). At the beginning of the story, we see "a woman stood insignificantly trapped between the jolting black wagons and the hedge" (Lawrence, 1998: 26). "She was a tall woman of imperious mien, handsome, with definite black eyebrows" (Lawrence, 1998: 27). And she is calm and set, though she is disappointed in finding her husband in the miners back home. From her conversation with her father who is an engine-driver and married recently, we know that she is an educated woman who has her own view and speaks it out straight. Her brief blame for her father's hurried marriage shows her attitude towards marriage and implies that it might be her self's experience which has caused her to come to "this dirty hole, rats and all" (Lawrence, 1998: 32). We also get information of her husband, a drinker and "can do nothing with his money but make a beast of himself" (Lawrence, 1998: 28). His image as an irresponsible husband and father is impressed more deeply in our mind through Elizabeth's later complaint and neighbors' deplored words. On the other hand, Elizabeth proves to be a responsible wife and mother for she is very hardworking and economical to make this poor family tidy and not lack of clothes and food. Moreover, she tries to change her husband all the time. Even when she has known that Walter had an accident, she plans to "get him away from the drink and his hateful ways... while he was ill” (Lawrence, 1998: 37).

Until the appearance of Walter's mother who told us something different about his son, we have no doubt that the failed marriage is due to the faults of the husband.

“He was a happy lad at home, only full of spirits.... You've had a sight o' trouble with him, Elizabeth, you have indeed. But he was a jolly enough lad wi' me, he was, I can assure you. I don' know how it is..." (Lawrence, 1998: 37)

Elizabeth seemed to be deaf to the mother-in-law's pleading for her son at first. However, when both of the two watched the clear body, the mother-in-law's words became a kind of activator.

"He went peaceful, Lizzie - peaceful as sleep. Isn't him beautiful, the lamb? Ay - he must ha'made his peace. The lamb, the dead lamb. Eh, he had a hearty laugh. I loved to hear it. He had the heartiest laugh, Lizzie, as a lad-" (Lawrence, 1998: 43)

"Elizabeth looked up." (Ibid.) She asked herself:

"Who am I? What have I been doing? ... What wrong have I done? What was that I have been living with?" (Ibid.)

"And now she saw, and turned silent in seeing. For she had been wrong. She had said he was something he was not; she had felt familiar with him" (Ibid.). And "his look was other than hers, his way was not her way. She had denied him what he was - she saw it now" (Lawrence, 1998: 43-44). "She was a mother - but how awful she knew it now to have been a wife. And he, dead now, how awful he must have felt it to be a husband" (Lawrence, 1998: 44).

Consequently, we know the truth previously hidden. Although the character of the husband never says a word, Lawrence conveys a lot about his character and his life. Elizabeth "saw the father in her [male] child's indifference in all but himself" (Lawrence, 1998: 29) and said he was as bad as his father. Otherwise, from Mr. Rigley's 
blue scar that was "caused by a wound got in the pit" (Lawrence, 1998: 35), we can know the danger of the work. Elizabeth, as an educated woman, is different from her uneducated husband in a lot of ways. It is probably unjust for her to see his ways as hateful ones, and to fight a husband blindly. Her misunderstandings towards him and efforts to change him as well as the pressure and monotony of his work have turned the husband to be a man out of spirits and hearty laugh. He works in the dark mine during daytime, climbs out in dusk and faces a home in gloom. He meets no light in his life. So he could only look for warmth in the "Lord Nelson" today, the "Prince of Wales" tomorrow and maybe the "Yew" the day after. He has to be an awful husband and his awful wife has made him sit at his own hearth like a stranger (Lawrence, 1998: 28).

What is more, the gap between the wife and husband is not narrowed by their children. In addition to a girl and a five-year-old boy, Elizabeth is going to have a third child soon, after four or five months. In her epiphany, Elizabeth realizes that the "children had come, for some mysterious reason, out of both of them. But the children did not unite them" (Lawrence, 1998: 44). When we reread the part before, we can see this cruel fact. The male child, who seems to be more like his father often worries and annoys his mother. His character and behaviors reminds Elizabeth of his "bad" father. Otherwise, while waiting for the father, "the children played, subduedly intent... united in fear of the mother's wrath, and in dread of their father's home-coming" (Lawrence, 1998: 32). Elizabeth, as a mother, has seen their unhappiness and uneasiness and "her heart burst with anger at their father who cause all three such distress" (Lawrence, 1998: 33). Therefore, the children could do nothing to relax the tension between their father and mother.

Epiphany is "a sudden spiritual manifestation, whether in the vulgarity of speech or of gesture or in memorable phase of the mind itself" (Fargneli, 1995: 66). The mother-in-law's nagging and Elizabeth self's touches to Walter's body play a crucial role in the moment of individual revelation. First "she embraced the body of her husband, with cheek and lips" (Lawrence, 1998: 42), and "put her face against his neck" (Ibid.) by instinct, but "she was driven away" (Ibid.) and got no connection. Then confronted by the naïve dignity of his dead body, she feels how inviolable he is - and she resists being so countermanded. She is accustomed to him as a predictable personality: husband, father, miner, and drinker. She cannot believe in this strange other, so she reaches out and lay "her hand on him, in claim" (Ibid.). She is attempting to claim him as her idea of him. But she cannot. He is impregnable. Later, washing the body, reaching out and touching him for the second time, she realizes the dark truth of his otherness. "The distance between them was so infinite a gap she must look across" (Lawrence, 1998: 44). And the essence of this is "the utter isolation of the human soul" (Lawrence, 1998: 42).

Keith Cushman says: "The relationship between man and woman is at the center of Lawrence's mature vision; however, even in the most intimate relationship there is always an unbridgeable gulf" (McCabe, 1987). The gap between Walter and Elizabeth is inevitable, whether he had been her husband or their relationship had become hopeless long before he died. In fact, what becomes evident, through detail and detail, is that the utter isolation exists everywhere, not only between husband and wife, but also parents and children, human and human, even human and nature. We see this in and yet beyond Elizabeth's epiphany while within the author' elaboration of the whole story.

Furthermore, in "Odour of Chrysanthemums", one of Lawrence's early masterpieces, the author also begins to think more about the life and death. "Lawrence's point is that death reveals that real self arrested in a moment of transit between life and death" (Ibid.). 
It is a moment of perfect balance when the people become inviolate and pure. As Elizabeth perceives Walter's otherness, she realizes that her former conception of him was far from his real self: "I have been fighting a husband who did not exist. He existed all the time. What wrong have I done? What was that I have been living with? There lies the reality, this man" (Lawrence, 1998: 43). Walter has seemed to be already dead in their failed marriage while he was alive. Nevertheless, Elizabeth and her mother-in-law "never forgot it was death, and the touch of the man's dead body gave them strange emotions" (Lawrence, 1998: 42). Feeling the utter alienation from him, Elizabeth realizes that she was just as far from him alive as dead. Walter wins the honor of his wife and convinces her of his individuality only when he is beyond self-assertion. And she finally discovers that death itself "symbolize the separate intact otherness of every human soul" (McCabe, 1987). Every person should not be defined or claimed by anything or anyone in life. He/She is just himself/herself.

Elizabeth has learned a lot from the death of her husband. She will at least treat her male child more kindly and have a life more magnanimous in future. And we have learned a lot from her epiphany especially in the aspect of marriage and life. We are fortunate to have a chance to do self-reflection without any loss. There is no definite way for us to get across the gap and diminish the isolation. But Lawrence suggests that people "ought to learn to be naked and handsome... And that's the only way to solve the industrial problem: train the people to be able to live and live in handsomeness, without needing to spend" (Lawrence, 1960: 315). And the people who are trapped in their own thoughts "should be alive and frisky, and acknowledge the great Pan. He's the only god for the masses, forever" (Ibid.).

\section{References}

[1] Fernihough, Anne. The Cambridge Companion to D. H. Lawrence[C]. Shanghai: Shanghai Foreign Language Education Press, 2003.

[2] Fargneli, A. Nicholas, et al. James Joyce A to Z: The Essential Reference to the Life and Work [Z]. New York: Facts In File, Inc., 1995.

[3] Hudspeth, Robert N.. Lawrence's "Odour of Chrysanthemums": Isolation and Paradox[J]. Studies in Short Fiction 1969(5), 630-36.

[4] Lawrence, D. H.. Lady Chatterley's Love[Z]. Harmondsworth: Penguin Books, 1960.

[5] "Odour of Chysanthemums". D. H. Lawrence: England, My England and Other Stories[Z]. London: Phoenix, 1998, 26-45.

[6] Sons and Lovers[Z]. Harmondsworth: Penguin Books, 1979.

[7] Leavis, F. R.. D. H. Lawrence: Novelist. Harmondsworth: Penguin Books Ltd, 1964.

[8] McCabe, T. H.. The Otherness of D. H. Lawrence's "Odour of Chrysanthemums"[J]. The D. H. Lawrence Review 19 (2). 1987, 149-56.

[9] Salgado, Gamini. A Preface to D. H. Lawrence[M]. Beijing: Peking University Press, 2005.

[10] Schulz,Volker. D. H. Lawrence's Early Masterpiece of Short Fiction: "Odour of Chrysanthemums"[J]. Studies in Short Fiction 28(3). 1991, 363-69. 